Semarang

State University

Undergraduate

LAWE

SOCIETY

REVIEW

VOLUME 1 ISSUE 1, JANUARY 2021
ISSN (Print): XXXX-XXXX ISSN (Online): XXXX-XXXX

\author{
History of Article \\ Submitted: November 2020 \\ Revised: December 2020 \\ Accepted: January 2021
}

How to cite:

Dwiyanti, I. (2021). The Criminal Penalties for LGBT in a Human Rights Perspective. Semarang State University Undergraduate Law and Society Review, 1(1), 1-18. https://doi.org/10.15294/lsr.v1i1.49835

(C) 2021 Authors. This work is licensed under a AttributionNonCommercial-ShareAlike 4.0 International (CC BY-NC-SA 4.0). All writings published in this journal are personal views of the authors and do not represent the views of this journal and the author's affiliated institutions.

\title{
The Criminal Penalties for LGBT in a Human Rights Perspective
}

\author{
Ita DWIYANTI \\ Feminism and Gender Equality Focal Point \\ Jakarta, INDONESIA \\ 凶thadwiee@gmail.com
}

\begin{abstract}
LGBT is essentially an unusual behavior of social aberrations. The cause of a person to be LGBT was due to several factors, genetic, hormonal, gender role discomfort, peer group interaction, social. Human rights exist from the day we are born until we die, and the function of human rights to protect all rights including to live and get legal protection. In terms of human rights criminalizing a person is an offense for depriving them of their rights, but if there is a violation that man is doing, of course it is not a violation even though human rights existed from the moment we are born until we die. Court Decision Number 46/PUU-XIV/2016 becomes controversial because it is considered to have legalized LGBT. If read
\end{abstract}


properly Court decision No. 46/ UU-XIV/2016 this Court does not intend to legalize LGBT but more consider the good and bad.

KEYWORDS. LGBT; Human Rights; Criminalization; Gender Equality

\section{INTRODUCTION}

LGBT is an acronym that means Lesbian, Gay, Bisexual and Transgender. The world's first LGBT, Karl Heinrich Ulrichs, he was a civil servant in Germany until he was forced to resign in 1854 for homosexuality. Hermawan (2007: 72) emphasized that in homosexual Islam as a cruel act (fahisyah), it is as contained in the QS. Al-A'raf (80) and part of adultery, "And (We have also sent) Lut (to his people). (Remember) when he said to them, "Why do you work on the deeds of the Fahlythah, which no one has ever done (in this world) before you?" Surely you go to men to release your passions (to them), not to women, even you are a transcendent people". This verse describes the story of the Sodom at the time of the Prophet Lut, which at that time the prophets of Lut also had same-sex sexual orientation. Though the prophet Luth had warned and tried to show the right path.

Today, LGBT is increasingly in the spotlight because of the issue of LGBT legalization, due to the decision of the Constitutional Court Number 46/ PUU-XIV/2016. Many people publicly rejected social media. Because according to them LGBT legalization is tantamount to setbacks. In addition, Indonesia is not a liberal country that can easily accept all new regulations. Indonesia has a normative law in which the prevailing norms are still strong in some areas.

The emergence of issues regarding the legalization of LGBT inspires writers to analyze whether the decision of the Constitutional Court Number 46 / PUU-XIV / 2016 really legalize LGBT, and what kind of responses of the community around, especially the students. 


\section{LGBT: HISTORY \& DEVELOPMENT IN INDONESIA}

LGBT is essentially an unusual behaviour of social aberrations. According to Ritzer (2007) LGBT is an abbreviation that has the meaning of Lesbian, Gay, Bisexual and Transgender and the meaning of all these terms can be explained as follows:

1) Lesbian: Lesbian is a woman who loves or loves women, both physically and sexually and spiritually, so this is very distorted.

2) Gay: Gay is a man who likes and loves men, and these gay words are often mentioned to clarify or keep referring to homosexual behavior.

3) Bisexual: This bisexual is slightly different from the two above notions because the bisexual person is a person who can have an emotional and sexual relationship of the two sexes so this person can have a relationship with both men and women.

4) Transgender: The transgender is an inequality of the gender identity given to that person by gender, and a transgender may be included in people who are homosexual, bisexual, or heterosexual (Arifin, 2016).

\section{A. History of LGBT Existence}

Starting from the Era of the French Revolution in 1791 when secularism began to take place while religious roles especially churches were no longer relevant in social, political, and economic until the fall of the Ottoman Turks government, the Western society that was originally in the dark era began to free themselves from religious bond. This action has given rise to a society in the late 19th and early 20th centuries, which created human will without limit (humanism) as a god until the emergence of those who dare to champion the opposite sex oriented with freedom of will and human rights. Starting from here this moral illness began to spread throughout the world where Muslim countries were equally targeted (Oetomo, 2006). 
The term LGBT is generally adapted from the abbreviation "LGB" replacing gay phrases that are often used to refer to homosexuals late the mid-1980s. It is said that the gay phrase does not refer to all homosexuals such as lesbian, bisexual, and transsexuals (Aryanti, 2016).

\section{B. Development of LGBT in Indonesia}

The first new open gay organization in the country, Lambda Indonesia (LI), emerged in 1982. Almost at the same time, the organization of the Lesbian Lesbian Union (Parlesin) organization was formed. The expansion of the gay (and then lesbi) gesture of Indonesia occurred when media attention was focused on issues surrounding homosexuality, particularly with the establishment of GAYa NUSANTARA in 1987. The number of organizations increased from just two in the late 1980s to more than ten in 1993, when the Indonesian Lesbian and Gay Congress (KLGI) Congress was held in Kaliurang, Yogyakarta (Kartono, 1989).

The development of homosexual numbers in Indonesia increases annually, including non-heterosexual sexual orientation such as, bisexual and transgender. Statistical data show that 8-10 million male populations in Indonesia at one time involved homosexuality and some were still active doing so. YPKN survey results show that there are 5000 same-sex couples in Jakarta. While Oetomo estimates that $1 \%$ of Indonesia's total population is gay.

Some previous studies highlighted and confirmed the cause of someone being LGBT was due to several factors, According to Kartono (1989) the causes of homosexual behavior, among others:

1) Factor in the imbalance of sex hormones in a person's body.

2) The influence of the environment is not good or unfavorable for the development of normal sexual maturity. 
3) Someone is always looking for homosexual relationship satisfaction because it once experienced an exciting homosexual experience in adolescence.

4) A boy has experienced a traumatic experience with his mother resulting in hatred or antipathy towards his mother and all the women.

From the above statement certainly can be seen if LGBT not completely personal error but also surrounding. Urlich was regarded as the first gay person to openly voice homosexual rights in 1867. He argued that homosexuality was, 'innate conditions' not corruption that could be learned, as was the view prevailing at the time (Wikipedia, "Ulrich")

Quoting from bbc.com Indonesia that three months after the Brexit vote, homophobic attacks increased $147 \%$. Similar concerns also occur on the opposite continent. US Vice President Mike Pence stamped same-sex marriage and signed a law that legalized the business sector to refuse gay and transgender customers on the basis of religious freedom. LGBT also faces the risks of increasing health problems (Soekanto, 1981).

Doob once posed a theory, which he called the piecemealness of change. The point is that if a strongly entrenched and highly satisfactory behavior pattern wants to be changed, then the change will occur only when certain elements are replaced. Therefore, his theory is called piecemeal. It is the same, when a behavior must be learned, it will take place part by part, or element by element. To then be studied thoroughly (Muladi, 2005).

Social change through social engineering must first start from a change of way of thinking. Social change will not go in the planned direction if thinking errors are still practiced. Mistaken thinking such as the impasse of thinking by various circles, including scientists and the myths are still believed by some people. Social engineering is done because of the emergence of social problems. Social problems arise because of a discrepancy between what should be, desirable (das sollen) with what comes true (das sein) (Muladi, 2005). 
In this case the social engineering process can start from a change of attitude and individual values, especially in understanding the existence of a communication technology. Social engineering is essentially a part of social action. Social action is a collective action to reduce or overcome social problems (Santoso, 2016; Sofwatin, Alfiani, Nurjanah, \& Mukti, 2019). Furthermore, this phenomenon raises some controversial issues, especially on criminalization for LGBT actors in Indonesia.

\section{LEGAL ANALYSIS ON CRIMINALIZATION OF LGBT IN INDONESIA: A CONTROVERSIAL ISSUE IN HUMAN RIGHTS}

In terms of human rights criminalizing a person is an offense for depriving them of their rights but if there is a violation that man does, of course it is not a violation even though human rights existed from the moment we were born until we die, and the function of human rights to protect all rights including to live and have legal protection. Since the law is there to regulate every human being, there will be abuses of power, riots, mass protests, etc. that is why the law is dynamic because from year to year there are always social changes that occur (Arifin, 2016; Wieringa, 2019).

LGBT activists are always taking refuge in the name of human rights. According to their logic that LGBTs should be protected by their very nature, especially their sexual rights towards same sex. Another excuse is that they in the United States Uncle Sam has legalized marriage of different religions, then the superpower that puts the human rights should be emulated by other countries in an effort to protect the rights of citizens. How about Indonesia ? in the context of Indonesianness, is LBGT undergoing the concept of human rights or violating human rights? (Muladi, 2005; Muthmainnah, 2016)

The principles of human rights can be seen in a variety of instruments, including: 
1) The 1945 Constitution, as set forth in Article 28I, Article 28J of the 1945 Constitution of the Republic of Indonesia.

2) Law Number 39 of 1999 on Human Rights, in Chapter I on General Provisions and Chapter II on Basic Principles

Where in the two instruments above can be concluded that: Human rights is a set of rights inherent in the nature and existence of human beings as God Almighty God, and is a grace of God that must be respected, upheld and protected not only by the state but also by everyone, and humans do not only have human rights but clearly stated that human also has a basic obligation where when the obligation is not implemented it will not be possible the implementation and enforcement of human rights, it as a balancing the enforceability of human rights (Munajat, 2017; Ridwan \& Wu, 2018).

The Indonesian Constitution, the 1945 Constitution of the Republic of Indonesia, in Article $28 \mathrm{~J}$ Paragraph (2), affirms that human rights can be limited (decreased) under the law for "... recognition and respect for the rights and freedoms of others and to fulfill fair demands in accordance with the considerations of 'moral, religious values, security and public order' in a democratic society". Strictly speaking, our constitution holds the notion that "human rights and freedoms are respected and protected but can be restricted and deprived of moral judgment, religious values, security and public order" (Harahap, 2016; Darmoko, 2017).

Everyone even groups always ask for his rights. If, for example, LGBT perpetrators are asked to be convicted, whereas LGBT's behavior desires its right, wants its freedom in public, of course, both very contradictory and totally unacceptable (Marzuki, 2011).

The current socio-economic, political and legal changes are being tested whether it is capable of transforming social relationships into a fairer relationship for the majority of the Indonesian people, or more of a lame social reform. Ongoing social change should have a transformative 
perspective, and a wide reach both in terms of methodology, agenda and motivation (Marzuki, 2011; Miskari, 2016).

From the various discourses and attempts to legalize LGBT, the attitude of the Indonesian people has no five responses:

1) International law (Human Rights) is often opposed to Pancasila so it is considered not in accordance with the ideals of the founders of the nation if it is still enforced. Thus, the rejection of Pancasila against LGBT is wholly incompatible with human rights, because every country has certain limits on the application of human rights.

2) Human rights can only be realized under the laws of Pancasila and the 1945 Constitution because they are part of the control of human actions of Indonesia. LGBT as a human rights product is far from the value of Pancasila, UUD 45 and the character of the Indonesian nation.

3) International human rights is a new imperialist agenda agenda to be rejected. One of them through LGBT movement

4) International human rights are incompatible with the religious values of Pancasila.

5) International human rights objectives have a hidden agenda, antireligion.

6) The Indonesian nation that is still upholding the value of humanity should keep the security and stability of the nation in preventing the LGBT.

It is not wrong to prosecute LGBT actors, because human rights contain moral principles, whereas LGBT is an aberration. So that should be avoided that the deviations that occur and the criminal just limit the perpetrators of the community can not cure. Criminal is only a last act. Because a criminal like a double-edged sword is slicing his own flesh. But of course when there is a law that legitimate (Murdiana, 2017; Badgett, Hasenbush, \& Luhur, 2017).

Equality Before The Law is a legal principle that becomes a symbol of law enforcement so that the initial understanding to be understood in the formulation of the legal rules on LGBT should be linked to an 
understanding of a legal concept. Understanding the law, will be closely related to how to look at the law itself. Thus the worldview will be associated with LGBT understanding as the object of legal politics because the output of political law is the establishment of the rule of law.

The author himself conducted a random survey of several students from different departments and universities on the issue of LGBT legitimacy.

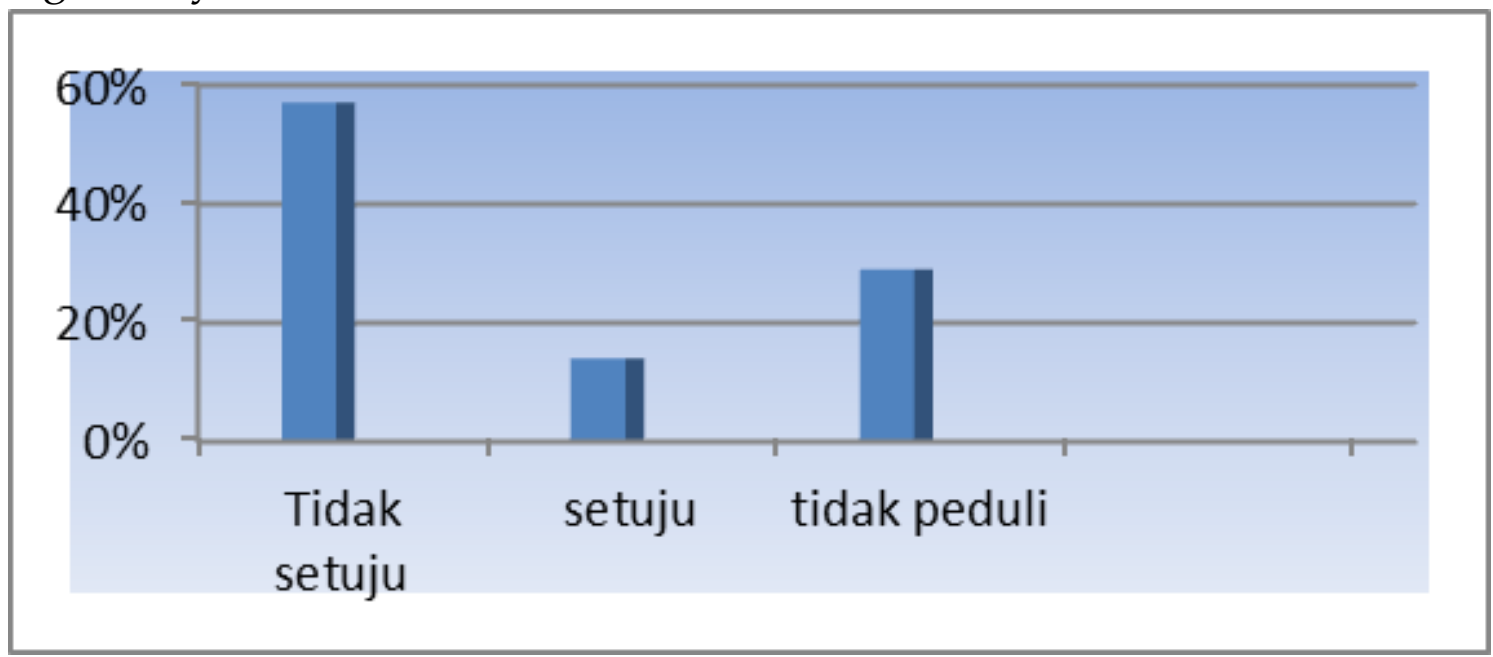

Source: Random Survey Authors, February 2018

Based on the above table can be seen if $57 \%$ of students disagree with LGBT legalized in Indonesia, because it is considered very disturbing community that certainly does not comply with the norm. While $14 \%$ of students agree with LGBT because it is legal according to them it is Human Rights. And 29\% of students do not care what happens.

For some people LGBT behavior has become an ordinary sight, but some argue that it violates the customs around. These customs are the guidelines of life throughout the region. The customs of a norm that must be maintained constantly, but as the times progressed it was not uncommon to find that adat was in opposition to the more modern changes such as the LGBT case (Constitutional Court, 2016; Velando, 2020).

In the petitum of Case Number 46/PUU-XIV/2016, the Petitioner filed a petition for judicial review of Article 292 against the 1945 Constitution to 
propose, to request for the deletion of adult phrases and phrases known or should be supposedly immature in Article 292 so that the formula becomes, "The person who commits lewd acts with another fellow is threatened with a maximum of 5 years."

Court Decision Number 46/PUU-XIV/2016 becomes controversial because it is considered to have legalized LGBT. If read properly Court of Decision Number 46/PUU-XIV/2016 this Constitutional Court does not intend to legalize LGBT but more considering good and bad because if the action of LGBT is done by child under age then the children also must be punished, is the function of the family, because the family is especially the two parents who have full rights in their children. As discussed earlier, LGBT causes not only from genes but also environmental influences. While LGBT actor who has grown up if convicted will not be more give the burden on the perpetrator especially the family left behind when the LGBT actor is the only backbone of the family. And LGBT behavior is a social aberration not a contagious disease through touch, so should the family and surrounding environment help to heal like embracing again so that LGBT actor will recover and can be normal again. Criminal is not the only way out so that no LGBT behavior, like any other criminal act.

In Indonesia there are many rules, there are many laws that govern but it does not guarantee that Indonesia can be $100 \%$ safe from all criminal acts because it is more and more criminal days with new crime mode. Increasing criminal acts, of course, have the reasons one of them is poverty and environmental factors. At a glance we look at the behavior of LGBT with criminal acts to have similarities if the environment can affect, but in behavior can not be equated, if LGBT behavior is convicted will not lead to new problems, such as in prison was still many acts of violence that occurred. Then, if the LGBT behavior is convicted then it will increasingly become victims of violence and bullying. The worst impact of it all is the LGBT actors will commit suicide (Arfanda \& Anwar, 2015).

According to the General Guidelines of the Transsexual Service (2008: 8-9), there are two problems faced by LGBT, as well as waria: 
a. Internal Issues

1) Feeling unclear identity and personality resulted in transsexual waria in a confused, awkward, excessive behavior, other effects difficult to find a job even depressed and suicidal.

2) Feeling isolated and feeling rejected resulting in the transvestites leave home, frustrated, lonely, seeking escape that is often the more detrimental to him.

3) Feel rejected and discriminated cause problems especially in social life, education, access work both formal and informal. The implication is that many transvestites find it difficult to get a job, education, or hampered the process of social interaction (Arfanda \& Anwar, 2015).

b. External Issues

1) Family problems

In the context of integration with the families of transvestites is often regarded as a disgrace and bring misfortune in the family so many of them do not recognize, excommunicate, discard, refuse, mock, and even alien.In addition, the family also close or withdraw from the community

2) Community Issues

Transsexuals and their communities are regarded as a person who performs irregularities that cause many problems in the community. Especially in terms of sexual problems that can accelerate the spread of STIs (Sexually Transmitted Infections) and HIV/AIDS. In addition, the community also has the stigma and rejection of transvestites and their families that have an impact on social exclusion, discrimination and harassment and other mistreatment.

3) Data

There is no accurate and up-to-date data about the profile picture of waria. This makes it difficult to formulate programs and policies, 
as well as work plans for relevant agencies/agencies and coordinate in an integrated manner.

4) The policy of non-optimal

Policies and regulations that provide social services to transvestites in a coordinated, integrated, and sustainable so that the needs of transvestites to access the world of education and employment have not received optimal attention (Santoso, 2016).

The community of LGBT people gets severe discrimination from the public. Starting from being excluded from work, considered a madman, as a criminal, and other discrimination issues. In 1951, Donald Webster Cory published The Homosexuals in America (Cory, 1951), which states that gay men and lesbians are legitimate minority groups. Until the 1950-1970s LGBT support community led the movement to ask for the elimination of discrimination against the LGBT community (Arfanda \& Anwar, 2015).

Transvestites were refused to become civil servants, employees in private offices, or other professions, even transvestites also experienced rejection and problems in administering ID cards. Other conditions describe the appearance of such a transvestite or transvestites in the world of entertainment is now a trend and much preferred by spectators or TV viewers, so it can be used as one alternative to earn income. Appearances such as a sissy that is quite funny and entertaining many imitated by people in everyday life, so as to encourage an increase in the number of transvestites. However, the stigma of transvestites as a group that behaves distorted or mental disorders still attached to transvestites (Arfanda \& Anwar, 2015).

Basically, symbolic interactionism is motivated by pragmatism so that every behavior of the actor has a meaning and how the actor acts according to his meaning in society. On the issue of transvestites, where there are benefits each expected by both parties. They act only because of the goals they want to achieve. The public wants the potential of transvestites as beauty experts and decorators of the bride, while transvestites need land to 
earn a living and acceptance from the community to be accepted even though not personally (Huda, 2015).

In Indonesia's positive law, same-sex sexual intercourse is governed in article 292 of the Penal Code (KUHP) stipulates that adults who commit lewd acts with other known and materially immature persons are threatened with the most imprisonable penalty five years old. In such passages same-sex derogatory behavior may be identified by homosexuality and the offense in that article applies only to homosexual perpetrators of minors (Galih, 2016).

Act No. 23 of 2006, unknown to lesbian, gay, bisexual and transgender terms, but people belonging to transgender and gender combinations can be enabled to change sexes, so there is a match between gender which he has with his behavior and appearance. In article 56 paragraph (1) of Law no. 23 of 2006, which states: The Recording of Other Significant Events shall be made by the Civil Registry Officer at the request of the Residents concerned after the establishment of a court of law which has obtained permanent legal force. Elucidation of Article 56 Paragraph (1) of Law Number 23 of 2006 states: "Other Important Events" means events determined by the district court to be registered with the Implementing Agencies, including changes in sex.

\section{CONCLUSION}

The phenomenon of Lesbian, Gay, Bisexual and Transgender (LGBT) is a deviation of sexual orientation that is contrary to human nature, religion and custom of Indonesian society. Because, although Indonesia is not an Islamic country, but still adhere to the easternization of Eastern (easternization). LGBT is essentially an unusual behaviour of social aberrations. The cause of a person to be LGBT was due to several factors, genetic, hormonal, gender role discomfort, peer group interaction, social. Human rights exist from the day we are born until we die, and the function 
of human rights to protect all rights including to live and get legal protection. In terms of human rights criminalizing a person is an offense for depriving them of their rights, but if there is a violation that man is doing, of course it is not a violation even though human rights existed from the moment we are born until we die. It is not wrong to prosecute LGBT actors, because human rights contain moral principles, whereas LGBT is an aberration. So that should be avoided that the deviations that occur and the criminal just limit the perpetrators of the community can not cure. Criminal is only a last act. Because a criminal like a double-edged sword is slicing his own flesh. But of course when there is a law that legitimate. Court Decision Number 46/PUU-XIV/2016 becomes controversial because it is considered to have legalized LGBT. If read properly Court decision No. 46/PUU-XIV/2016 this Court does not intend to legalize LGBT but more consider the good and bad.

\section{REFERENCES}

Arfanda, F., \& Anwar, S. (2015). Konstruksi Sosial Masyarakat Terhadap Waria. KRITIS: Jurnal Ilmu Sosial dan Ilmu Politik Universitas Hasanuddin, 1(1), 93-102.

Arifin, M. (2016). LGBT dalam Takaran Sosiologi Hukum. Yurisprudentia: Jurnal Hukum Ekonomi, 2(1), 52-64. https://doi.org/10.24952/yurisprudentia.v2i1.659

Aryanti, Z. (2017). Faktor resiko terjadinya LGBT pada anak dan remaja. Nizham Jurnal Studi Keislaman, 4(1), 42-49.

Asyari, F. (2018). LGBT dan Hukum Positif Indonesia. LEGALITAS, 2(2), 57-65. https://doi.org/10.31293/lg.v2i2.3385

Badgett, M. L., Hasenbush, A., \& Luhur, W. E. (2017). LGBT Exclusion in Indonesia and Its Economic Effects. Los Angles: Williams Institute, UCLA School of Law.

Constitutional Court. (2016). Putusan Mahkamah Konstitusi Nomor 


\section{6/PUU/XIV/2016}

Darmoko, M. (2017). LGBT Effect and its Impact in Indonesia (Sociology of Law's Perpective). In 1st International Conference on Culture, Arts and Humanities (ICCAH) (pp. 209-219).

Galih, Y. S. (2016). Suatu Telaah Lesbian, Gay, Biseksual, Transgender (Lgbt) Dalam Perspektif Hukum Positif. Jurnal Ilmiah Galuh Justisi, 4(1), 92-106. http://dx.doi.org/10.25157/jigj.v4i1.413

Harahap, R. D. (2016). LGBT di Indonesia: Perspektif Hukum Islam, HAM, Psikologi dan Pendekatan Mașlaḥah. Al-Ahkam, 26(2), 223-248. http://dx.doi.org/10.21580/ahkam.2016.26.2.991

Hermawan, A. H. (2007). Bukan Salah Tuhan Mengazab: Ketika Perzinaan Menjadi Berhala Kehidupan. Solo: Tiga Serangkai.

Huda, F. I. (2015). Perilaku Seksual Kaum Gay dalam Tinjauan Hukum Islam dan Perundang-Undangan di Indonesia (Studi Kasus pada Komunitas Gay di Salatiga). Thesis, IAIN Salatiga.

Kartono, K. (1989). Psikologi Abnormal dan Abnormalitas Seksual. Bandung: CV. Mandar Maju.

Marzuki, S. (2011). Tragedi Politik Hukum HAM. Yogyakarta: Pustaka Pelajar

Miskari, M. (2016). Wacana Melegalkan LGBT di Indonesia (Studi Analisis LGBT dalam Perspektif HAM dan Pancasila). Raheema: Jurnal Studi Gender dan Anak, 3(1), 44-54. https://doi.org/10.24260/raheema.v3i1.559

Muladi, M. (2005). Hak Asasi Manusia: Hakekat, Konsep dan Implikasinya dalam Perspektif Hukum dan Masyarakat. Bandung: Refika Aditama

Munajat, M. (2017). LGBT Perspektif Hukum Pidana Islam. Jurnal Cakrawala Hukum, 11(1), 109-119. https://ejournal.up45.ac.id/index.php/cakrawalahukum/article/view/192

Murdiana, E. (2017). LGBT Perspektif Legal Reform (Sebuah Kajian Legal Substansi dalam Upaya Pembentukan Ius Constituendum). Jurnal Mahkamah: Kajian Ilmu Hukum Dan Hukum Islam, 2(2), 193-216. 
Muthmainnah, Y. (2016). LGBT Human Rights in Indonesian Policies. Indonesian Feminist Journal, 4(1), 13-29.

Oetomo, D. (2006). Memperjuangkan Hak Asasi Manusia Berdasarkan Identitas Gender Dan Seksualitas di Indonesia. Surabaya: Yayasan GAYa NUSANTARA.

Ridwan, R., \& Wu, J. (2018). 'Being young and LGBT, what could be worse?' Analysis of youth LGBT activism in Indonesia: challenges and ways forward. Gender \& Development, 26(1), 121-138. https://doi.org/10.1080/13552074.2018.1429103

Ritzer, G. (2007). Teori Sosiologi Modern. Jakarta: Kencana.

Santoso, M. B. (2016). LGBT dalam Perspektif Hak Asasi Manusia. Share: Social Work Journal, 6(2),

154-272. https://doi.org/10.24198/share.v6i2.13206

Soekanto, S. (1981). Hukum Adat Indonesia. Jakarta: Raja Grafindo Persada. Sofwatin, U., Alfiani, D., Nurjanah, N., \& Mukti, S. D. (2019). LGBT in Legal and Criminology Aspects. Unnes Law Journal: Jurnal Hukum Universitas Negeri Semarang, 5(1). https://doi.org/10.15294/ulj.v5i1.31053

Velando, M. (2020). Analysis of Constitutional Court Decision Number 46/PUU-XIV/2016 Related to LGBT and Community Attitude. Journal of Law and Legal Reform, 1(2), 259-272. https://doi.org/10.15294/jllr.v1i2.35767

Wieringa, S. E. (2019). Criminalisation of homosexuality in Indonesia: The role of the constitution and civil society. Australian Journal of Asian Law, 20(1). https://ssrn.com/abstract=3488561

Yansyah, R., \& Rahayu, R. (2018). Globalisasi Lesbian, Gay, Biseksual, dan Transgender (LGBT): Perspektif HAM dan Agama dalam Lingkup Hukum di Indonesia. Law Reform, 14(1), 132-146. https://doi.org/10.14710/lr.v14i1.20242

$\begin{array}{lll}\text { [...] } & \text { Harl Heinrich } & \text { Ulrich", } \\ \text { https://en.wikipedia.org/wiki/Karl_Heinrich_Ulrichs } & \end{array}$




\section{Conflicting Interest Statement}

All authors declared that there is no potential conflict of interest on publishing this article.

\section{Funding}

None

\section{Publishing Ethical and Originality Statement}

All authors declared that this work is original and has never been published in any form and in any media, nor is it under consideration for publication in any journal, and all sources cited in this work refer to the basic standards of scientific citation.

\section{ABOUT AUTHOR(S)}

The author is a researcher on the Feminism and Gender Equality Focal Point, Jakarta, Indonesia. Obtained a bachelor's degree from Semarang State University. In addition, the author has also been actively involved in the management of the student journal "Lex Scientia Law Review" (a nationally accredited journal), besides that the author has also been actively involved in several scientific professional organizations, ranging from the Indonesian Law Student Writers Association (IPHMI), the Young Scientists Association International, and Student Law Journal Management Community. 
Gender equality is the goal that will help abolish poverty that will create more equal economies, fairer societies, and happier men, women, and children.

Graça Machel 